\title{
SISTEM PENDUKUNG KEPUTUSAN \\ PEMUTUSAN HUBUNGAN KERJA TERHADAP KARYAWAN DI PT NOBI PUTRA ANGKASA
}

\author{
Dona Novandri Astomo ${ }^{1}$, Sita Anggraeni ${ }^{2}$ \\ ${ }^{1,2}$ STMIK Nusa Mandiri \\ 1,2 Jalan Jatiwaringin No 2, Jakarta Timur \\ E-mail : donovast@gmail.com ${ }^{1}$, sita.sia@nusamandiri.ac.id ${ }^{2}$
}

\begin{abstract}
ABSTRAK
Perusahaan sebaiknya memiliki sebuah sistem manajemen sehat bekerja secara profesional dan memberikan keefektifan yang tepat, hal tersebut tidak lepas dari dukungan dari sumber daya manusia yang memiliki ketrampilan pada bidangnya. Beberapa perusahaan terkadang tidak tepat dalam Pemutusan Hubungan Kerja sehingga kinerja sebuah perusahaan akan turun secara signifikan. Dalam penentuan pemutusan hubungan kerja memiliki beberapa kriteria yang kiranya bisa menjadi sebuah penilaian. PT. Nobi Putra Angkasa meningkatkan kemajuan perusahaan salah satunya ditinjau dari kualitas sumber daya manusia yang terdapat pada organisasi atau perusahaan, apabila sumber daya manusia dapat diorganisir dengan baik, maka diharapkan perusahaan dapat menjalankan semua proses usahanya dengan baik. Penilaian kinerja karyawan merupakan hal sangat penting dalam melakukan proses PHK. Selain itu juga masalah lain yaitu terkadang departemen HRD yang tidak bersifat obyektif dalam menentukan karyawan yang berhak diPHK Salah satu metode sistem rekomendasi dalam menentukan persoalan yang melibatkan multi kriteria adalah dengan metode Simple Additive Weighting (SAW) dipilih karena metode ini memberikan kepentingan yang lebih dominan. Pada penelitian ini dibangun sistem aplikasi yang menggunakan metode Simple Additive Weighting (SAW). Dengan menggunakan meode ini dapat membantu dalam penilaian dari kreteria yang ditentukan perusahaan dan kiranya oleh perusahaan dapat dijadikan sebagai penunjang keputusan dalam pemutusan hubungan kerja
\end{abstract}

Kata kunci:Simple Additive Weighting (SAW), PHK, SPK, Nobi

\section{PENDAHULUAN}

PHK bahasa lainnya yakni pemutusan hubungan kerja dalam hukum perburuhan di Indonesia. UU No. 13 Tahun 2003 tentang Ketenagakerjaan (UU Ketenaga kerjaan) mendefinisikan PHK dalam arti pengakhiran dalam sebuah hubungan kerja disebabkan oleh hal tertentu yang berakibat teroutusnya hak dan kewajiban diantara pekerja dan pihak pengusaha. Secara normatif, ada dua jenis PHK, yaitu PHK secara sukarela dan PHK dengan tidak sukarela. Dalam ini ada beberapa sebab sehingga terputusnya hubungan kerja yang tercantum dalam UU Ketenagakerjaan.

PHK sukarela secara real dapat digambarkan yakni seperti pengunduran diri seorang buruh tanpa adanya sebuah paksaan dan tekanan tertentu dari pihak manapun atau bisa dicontohkan berakhirnya perjanjian masa kontrak, tidak lolos dalam masa percobaan (probation), ketika sudah memasuki usia pensiun dan bila terjadi meninggalnya buruh tersebut. PHK tidak sukarela dapat diilustrasikan yakni pada saat buruh melakukan sebuah kesalahan atau melanggar dari norma yang ada misalnya seperti mencuri atau menggelapkan uang milik perusahaan atau telah terjebak dalam perbuatan asusila atau perjudian di wilayah lingkungan kerja. Hal tersebut dalam sebuah keputusan PHK karena kesalahan berat telah diatur dalam pasal 158 UU Ketenagakerjaan. Pasal ini bisa pula diajukan judicial review ke Mahkamah Konstitusi. Mahkamah Konstitusi dalam memberi keputusan yakni kesalahan berat yang telah dituduhkan ke seorang buruh harus terbukti benar dahulu oleh keputusan peradilan pidana di pengadilan umum.

Dalam suatu kasus PHK tidak sukarela dapat terjadi saat buruh melanggar pasal-pasal dalam perjanjian kerja, PKB atau PP. Perusahaan 
sedang melakukan peleburan, penggabungan dan atau perubahan status, memiliki opsi untuk mempertahankan atau memutuskan hubungan kerja. Kontekstual dalam PHK tidak sukarela ini,akan terjadi berakhirnya hubungan kerja antara pengusaha dengan buruh setelah ditetapkan oleh Lembaga Penyelesaian Perselisihan Hubungan Industrial, namun tidak terjadi hal demikian dengan PHK yang sukarela

Menurut [1] "Sumber Daya Manusia sebagai pelaku aktif dalam aktivitas perusahaan perlu mendapat pengelolaan yang baik oleh perusahaan. Karyawan dengan prestasi kerja yang buruk dapat didemosikan, dimutasi bahkan dilakukan pemutusan hubungan kerjanya. Sebaliknya, sebagai bentuk apresiasi atas kinerja para karyawan yang berkinerja baik, pihak perusahaan akan memberikan kompensasi, baik secara langsung maupun tidak langsung."

Menurut [2] "Setiap perusahaan melakukan PHK dengan tujuan untuk mempertahankan kelangsungan hidup, berkembang, kemampuan untuk bersaing serta mendapatkan laba."

PT. Nobi Putra Angkasa meningkatkan kemajuan perusahaan perusahaan salah satunya ditinjau dari kualitas sumber daya manusia tersebut menjadi produktif. PT. Nobi Putra Angkasa meningkatkan kemajuan perusahaan salah satunya ditinjau dari kualitas sumber daya manusia yang terdapat pada organisasi atau perusahaan, apabila sumber daya manusia dapat diorganisir dengan baik, maka diharapkan perusahaan dapat menjalankan semua proses usahanya dengan baik. Penilaian kinerja karyawan merupakan hal sangat penting dalam melakukan proses PHK. Selain itu juga masalah lain yaitu terkadang departemen HRD yang tidak bersifat obyektif dalam menentukan karyawan yang berhak diPHK.

Menurut [3] "Belum efektifnya sistem informasi dan masih banyak terdapat kesalahan dalam proses perekapan data karena banyaknya data dan kurangnya waktu yang tersedia untuk mengevaluasi hasil kinerja karyawan. Dan ditambah lagi dengan beberapa karyawan yang bekerja semaunya dan tidak sesuai aturan yang telah ditetapkan oleh peraturan perusahaan, seperti : tidak mampu menyelesaikan pekerjaan dengan target waktu yang telah ditetapkan, kurang cakap dalam bekerja, mangkir dan tidak disiplin."

Hal ini menyebabkan kurangnya nilai hasil kinerja yang seharusnya mencapai target dalam kurun waktu yang telah ditentukan oleh PT.Nobi Putra Angkasa.

Beberapa penelitian sebelumnya menggunakan metode Simple Additive Weighting (SAW) Perancangan Sistem
Pendukung Keputusan Pemberhentian Karyawan Harian Lepas Studi Kasus di CV Mitra Abadi Jaya Tangerang [3], Penggunaan Simple Additive Weighting (SAW) Pada penelitian ini adalah Sistem Pendukung Keputusan Pemutusan Hubungan Kerja terhadap Karyawan di PT Nobi Putra Angkasa.

Menurut [4] "Keputusan adalah proses penelusuran masalah yang berawal dari latar belakang masalah,identifikasi masalah hingga kepada terbentuknya kesimpulan atau rekomendasi. Rekomendasi itulah yang selanjutnya dipakai dan digunakan sebagai pedoman basis dalam pengambilan keputusan. Oleh karena itu, begitu besarnya pengaruh yang akan terjadi jika seandainya rekomendasi yang dihasilkan tersebut terdapat kekeliruan atau adanya kesalahan-kesalahan yang tersembunyi karena faktor ketidakhati-hatian dalam melakukan pengkajian masalah.”

Sistem Pendukung Keputusan adalah Suatu sistem informasi berbasis komputer mengkombinasikan model dan data untuk menyediakan dukungan kepada pengambil keputusan dalam memecahkan masalah semi terstruktur atau masalah ketergantungan yang melibatkan user secara mendalam. SPK dirancang untuk mendukung seluruh tahap pengambilan keputusan mulai dari mengidentifikasikan masalah, memilih data yang relevan dan menentukan pendekatan yang digunakan dalam proses pengambilan keputusan, sampai mengevaluasi alternatif [5]

Menurut [6] "Sistem Pendukung Keputusan (SPK) biasanya dibangun untuk mendukung solusi atas suatu masalah atau untuk suatupeluang”. Aplikasi Sistem Pendukung Keputusan (SPK) digunakan dalampengambilan keputusan. Aplikasi Sistem Pendukung Keputusan (SPK) menggunakan CBIS (Computer Based Information Systems) yang fleksibel, interaktif, dan dapatdiadaptasi, yang dikembangkan untuk mendukung solusi atas masalah manajemen spesifik yang tidak terstruktur.

Menurut Bonczek dalam [6], "Sistem Pendukung Keputusan sebagai sistem berbasis computer yang terdiri dari tiga komponen yangsaling berinteraksi, sistem bahasa (mekanisme untuk memberikan komunikasi antara pengguna dan komponen sistem pendukung keputusan lain), sistem pengetahuan (respositori pengetahuan domain masalah yang ada pada sistem pendukung keputusan atau sebagai data atau sebagai prosedur), dan sistem pemrosesan masalah (hubungan antara dua komponen lainnya, terdiri dari satu atau lebih 
kapabilitas manipulasi masalah umum yang diperlukan untuk mengambil keputusan)".

Menurut Alarifi, H. Dalam [7] mengemukakan bahwa "Sistem Pedukung Keputusan atau yang biasa disebut Decision Support System (DSS) adalah sebuah sistem yang ditujukan untuk mendukung para pengambilan keputusan manajerial untuk masalah semiterstruktur.

Menurut [8] Undang-Undang RI No. 13 Tahun 2003 tentang ketenagakerjaan,Pasal 1 ayat 2 "Tenaga Kerja adalah Setiap orang yang mampu melakukan pekerjaan guna menghasilkan barang dan/atau jasa baik untuk memenuhi kebutuhan sendiri maupun masyarakat".

Menurut [9] Undang-Undang No.14 Tahun 1969 tentang Ketentuan- Ketentuan Pokok Mengenai Tenaga Kerja dalam pasal 1 dikatakan bahwa karyawan adalah tenaga kerja yang melakukan pekerjaan dan memberikan hasil kerjanya kepada pengusaha yang mengerjakan dimana hasil karyawannya itu sesuai dengan profesi atau pekerjaan atas dasar keahlian sebagai mata pencariannya. Sesuai dengan hal tersebut menurut [9] Undang-Undang No. 14 Tahun 1969 tentang Pokok Tenaga Kerja,tenaga kerja adalah tiap orang yang mampu melaksanakan pekerjaan, baik di dalam maupun di luar hubungan kerja guna menghasilkan jasa atau barang untuk memenuhi kebutuhan masyarakat.

Menurut [10], "Pemutusan Hubungan Kerja adalah putusnya perikatan atau perjanjian antara perusahaan dengan karyawan / pekerja secara resmi kewajiban masing-masing pihak". Artinya pemutusan hubungan kerja, bahwa perjanjian antara karyawan dan perusahaan batal demi hukum. Karyawan / Pekerja tidak lagi memiliki kewajiban terhadap perusahaan dari pihak perusahaan tidak lagi memberikan hak-haknya kepada karyawan. Kecuali hak yang berkaitan dengan kompensasi karena sebab-sebab keluar yang diatur oleh peraturan yang berlaku seperti perjanjian kerja bersama antara pengusaha dengan pekerja.

\section{ISI PENELITIAN}

\subsection{Landasan Teori}

Berikut adalah landasan teori yang digunakan dalam penelitian ini.

\subsubsection{Simple Additive Weighting}

Menurut [11], "Metode Simple Additive Weighting sering juga dikenal dengan istilah metode penjumlahan terbobot". Konsep dasar metode Simple Additive Weighting adalah mencari penjumlahan terbobot dari rating kinerja pada setiap alternative pada semua atribut.
Metode Simple Additive Weighting disarankan untuk menyelesaikan masalah penyeleksian dalam sistem pengambilan keputusan yang memiliki banyak atribut. Metode Simple Additive Weighting membutuhkan proses normalisasi matriks keputusan (X) ke suatu skala yang didapat diperbandingkan dengan semua rating alternative yang ada. Langkah penyelesaian metode Simple Additive Weighting adalah sebagai berikut :

1. Menentukan kriteria-kriteria yang akan dijadikan acuan dalam menentukan pengambilan keputusan.

2. Menentukan rating kecocokan setiap alternatif pada setiap kriteria kemudian memodelkannya kedalam bilangan fuzzy setelah dikonversikan kebilangan crips.

3. Memberikan nilai bobot yang juga didapatkan berdasarkan nilai crips.

4. Melakukan normalisasi matriks dengan cara menghitung nilai rating kinerja ternormalisasi.

5. Melakukan proses perangkingan untuk setiap alternatif dengan cara mengalikan nilai bobot dengan nilai rating kinerja ternormalisasi.

6. Menentukan nilai preferensi untuk setiap alternatif dengan cara menjumlahkan hasil kali antara matriks ternormalisasi dengan nilai bobot.

Formula untuk melakukan normalisasi tersebut adalah sebagai berikut:

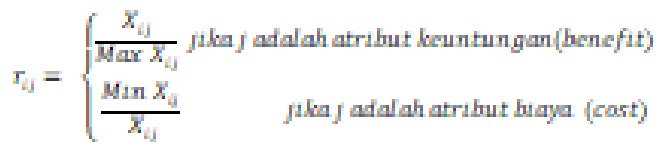

Dimana dengan $r_{\mathrm{ij}}$ adalah rating kinerja ternormalisasi dari alternatif $A_{\mathrm{i}}$ pada atribut $\mathrm{C}_{\mathrm{j}}: i$ $=1,2 \ldots, m$ dan $\mathrm{j}=1,2 \ldots, n$

Keterangan

1. Simbol rij adalah rating kinerja ternormalisasi.

2. Simbol xij adalah nilai atribut yang dimiliki dari setiap kriteria.

3. Simbol Max xij adalah nilai terbesar dari setiap kriteria $i$.

4. Simbol Min xij adalah nilai terkecil dari setiap kriteria $i$.

5. Benefit adalah jika nilai terbesar tersebut merupakan nilai terbaik.

6. Cost adalah jika nilai terkecil tersebut merupakan nilai terbaik.

Nilai preferensi untuk setiap alternatif $\left(V_{i}\right)$ diberikan rumus sebagai berikut:

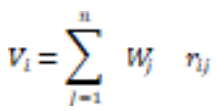


Keterangan

- $\quad V_{i}=$ ranking untuk setiapalternatif.

- $\quad W_{j}=$ nilai bobot ranking (dari setiap kriteria).

- $\quad r_{i j}=$ nilai rating kinerja ternormalisasi.

Nilai $V i$ yang lebih besar mengindikasikan bahwa alternatif $A_{i}$, lebih terpilih

\subsection{Metode Penelitian}

Adapun langkah-langkah penelitian seperti pada gambar 1

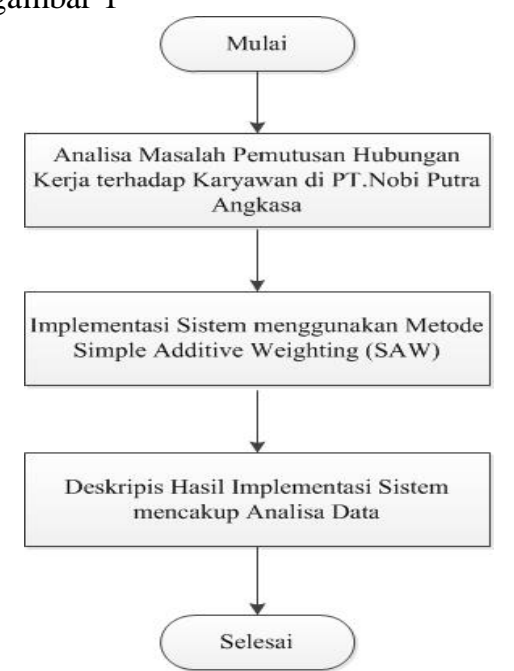

Gambar 1 Flowchart penelitian

Dalam Gambar 1 menjelaskan bahwa dalam pemutusan hubungan kerja karyawan PT Nobi Putra Angkasa menggunakan metode Simple Additive Weighting (SAW) Metode SAW termasuk kedalam metode Fuzzy Multi-Attribute Decision Making (FMADM), yang mana dalam penentuan bobot dan nilai variabel disetiap kreteria nya wajib menggunakan bilangan Fuzzy.

Dalam analisa kasus masalah pemutusan hubungan kerja karyawan PT Nobi Putra Angkasa dapat ditentukan oleh beberapa kriteria, dalam hal ini kriteria sudah disesuaikan Perusahaan dalam penilaiannya, kemudian hasil kriteria ini menghasilkan bobot yang mana , dapat menjadi acuan dari hasil bobot yang dihasilkan disesuaikan metode Simple Additive Weighting (SAW).

Dibawah ini terlihat yakni Tabel 1 gambaran beberapa kriteria penilaian yang menjadi dasar oleh perusahaan dalam penentuan bobot dalam kasus pemutusan hubungan kerja karyawan PT Nobi Putra Angkasa

Tabel 1. Tabel Kriteria Penilaian

\begin{tabular}{|c|c|}
\hline Kriteria & Keterangan \\
\hline $\mathrm{C} 1$ & Absensi \\
\hline $\mathrm{C} 2$ & Produktivitas \\
\hline $\mathrm{C} 3$ & Usia \\
\hline $\mathrm{C} 4$ & Sakit \\
\hline
\end{tabular}

Hasil paparan dari tabel kriteria diatas akan dipasangan dengan skala rating kecocokan menggunakan bilangan fuzzy, sehingga dapat diketahui bagamana bobot dari skala yang digunakan . berikut ini tabel 2 adalah hasil dari pasangan skala kecocokan dengan menggunakan bilangan fuzzy.

Tabel 2. Tabel Skala Rating Kecocokan menggunakan Bilangan Fuzzy

\begin{tabular}{|l|c|}
\hline \multicolumn{1}{|c|}{$\begin{array}{c}\text { Skala Rating } \\
\text { Kecocokan }\end{array}$} & Nilai \\
\hline Sangat Kurang (SK) & 1 \\
\hline Kurang (K) & 2 \\
\hline Cukup (C) & 3 \\
\hline Baik (B) & 4 \\
\hline
\end{tabular}

Setiap criteria $\left(\mathrm{C}_{\mathrm{j}}\right)$ akan dijabarkan dalam sebuah bobot, dan bobot tersebut telah dikonversi kedalam bilangan fuzzy, tabel 3 menggambarkan hasil uraian kriteria absensi lengkap dengan pembobotannya, begitu juga halnya tabel 4 menggambarkan hasil uraian kriteria produktivitas lengkap dengan pembobotannya serta tabel 5 menggambarkan hasil uraian kriteria usia lengkap dengan pembobotannya dan terakhir tabel 6 menggambarkan hasil uraian kriteria sakit lengkap dengan pembobotannya

Tabel 3. Tabel Kriteria Absensi

\begin{tabular}{|l|c|}
\hline \multicolumn{1}{|c|}{ Karakter } & $\begin{array}{c}\text { Nilai } \\
\text { (Bobot) }\end{array}$ \\
\hline Absen > 6 Hari & 1 \\
\hline $\begin{array}{l}\text { Pernah Absen 5-6 Hari } \\
\text { dalam 1(satu) Semester }\end{array}$ & 2 \\
\hline $\begin{array}{l}\text { Pernah Absen 3-4 Hari } \\
\text { dalam 1(satu) Semester }\end{array}$ & 3 \\
\hline $\begin{array}{l}\text { Pernah Absen 1-2 Hari } \\
\text { dalam 1(satu) Semester }\end{array}$ & 4 \\
\hline
\end{tabular}

Tabel 4. Tabel Kriteria Produktivitas

\begin{tabular}{|l|c|}
\hline \multicolumn{1}{|c|}{ Karakter } & $\begin{array}{c}\text { Nilai } \\
\text { (Bobot) }\end{array}$ \\
\hline Sangat Tidak Produktif & 1 \\
\hline Tidak Produktif & 2 \\
\hline Standart & 3 \\
\hline Produktif & 4 \\
\hline Sangat Produktif & 5 \\
\hline
\end{tabular}

Tabel 5. Tabel Kriteria Usia

\begin{tabular}{|l|c|}
\hline \multicolumn{1}{|c|}{ Karakter } & $\begin{array}{c}\text { Nilai } \\
\text { (Bobot) }\end{array}$ \\
\hline Lansia Akhir (56-65 Tahun) & 1 \\
\hline Lansia Awal (46-55 Tahun) & 2 \\
\hline Dewasa Akhir (36-45 Tahun) & 3 \\
\hline
\end{tabular}




\begin{tabular}{|l|l|}
\hline Dewasa Awal (26-35 Tahun) & 4 \\
\hline Remaja Akhir (18-25 Tahun) & 5 \\
\hline
\end{tabular}

Tabel 6. Tabel Kriteria Sakit

\begin{tabular}{|l|c|}
\hline \multicolumn{1}{|c|}{ Karakter } & $\begin{array}{c}\text { Nilai } \\
\text { (Bobot) }\end{array}$ \\
\hline $\begin{array}{l}\text { Sakit > 1 Bulan dalam 1(satu) } \\
\text { Semester }\end{array}$ & 1 \\
\hline $\begin{array}{l}\text { Pernah Sakit 6-29 Hari dalam } \\
\text { 1(satu) Semester }\end{array}$ & 2 \\
\hline $\begin{array}{l}\text { Pernah Sakit 3-5 Hari dalam } \\
\text { 1(satu) Semester }\end{array}$ & 3 \\
\hline $\begin{array}{l}\text { Pernah Sakit 1-2 Hari dalam } \\
\text { 1(satu) Semester }\end{array}$ & 4 \\
\hline $\begin{array}{l}\text { Tidak Pernah Sakit dalam } \\
\text { 1(satu) Semester }\end{array}$ & 5 \\
\hline
\end{tabular}

Dari Kriteria yang telah dijabarkan diatas maka pembuatan keputusan memberikan nilai bobot (W), berdasarkan tingkat kepentingan masing-masing kriteria yang dibutuhkan. Nilai bobot dari setiap kriteria adalah seperti gambar 7 dibawah ini :

Tabel 7. Tabel Kepentingan Kriteria

\begin{tabular}{|c|l|c|}
\hline $\begin{array}{c}\text { Kriteria } \\
\text { (C) }\end{array}$ & \multicolumn{1}{|c|}{ Bobot } & Nilai \\
\hline C1 & $\begin{array}{l}\text { Sangat Baik } \\
\text { (SB) }\end{array}$ & 5 \\
\hline C2 & Baik (B) & 4 \\
\hline C3 & Cukup (C) & 3 \\
\hline C4 & Kurang (K) & 2 \\
\hline
\end{tabular}

\subsection{Analisa Masalah Menggunakan Metode Simple Additive Weighting (SAW)}

Analisa masalah dalam kasus ini adalah pemutusan hubungan kerja pada PT Nobi Putra Angkasa , membutuhkan sebuah sistem pendukung keputusan (SPK) untuk menghitung dari hasil pembobotan dari beberapa kriteria yang ditentukan sesuai dengan tahapan metode Simple Additive Weighting (SAW) dan diharapkan dapat membantu pimpinan dalam menghasilkan solusi alternatif dalam pemecahan masalah yakni menghasilkan sebuah keputusan.

Kriteria kriteria tersebut digambarkan dalam bagan gambar 2 berikut ini :

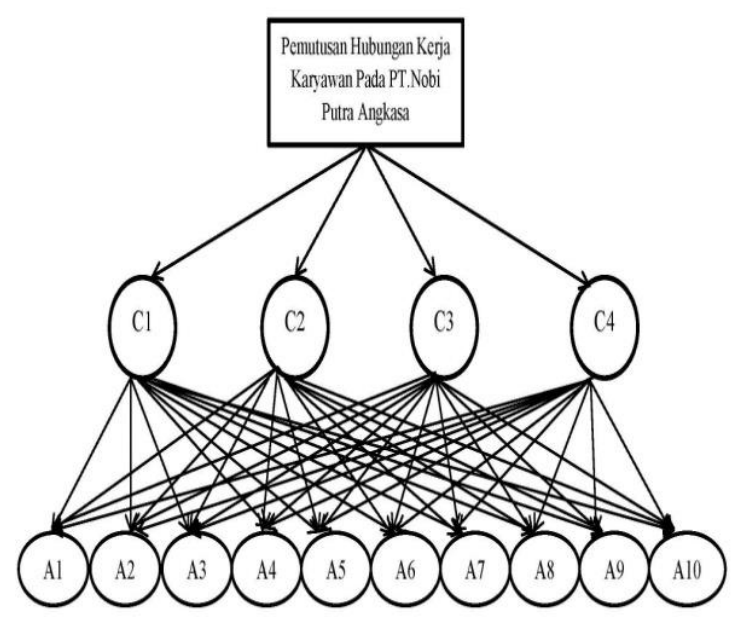

Gambar 2 Hirarki PHK Karyawan

\subsection{Pengolahan data menggunakan Metode Simple Additive Weighting(SAW)}

Proses pengolahan data dalam sistem penunjang keputusan ini menggunakan metode Simple Additive Weighting (SAW) dibagi menjadi empat tahapan, tahapan pertama penentuan beberapa kreteria yang sudah disepakati oleh perusahaan dalam hal ini adalah pimpinan, tahapan kedua adalah penetuan rating kecocokan dari kriteria yang telah ditentukan sebelumnya,tahapan ketiga pembuatan matrik dari hasil pembobotan dengan alternative yang tersedia dan tahapan terakhir adalah pembuatan perengkingan dari hasil perhitungan sebelumnya.

Adapun jumlah bobot dari hasil kriteria yang telah ditentukan tahapan sebelumnya bisa dilihat pada tabel 8 berikut ini :

Tabel 8 Tabel Bobot Kriteria

\begin{tabular}{|c|l|l|c|}
\hline No. & \multicolumn{1}{|c|}{ Kriteria } & \multicolumn{1}{|c|}{ Keterangan } & Bobot \\
\hline 1 & Absensi & Keuntungan & 0,35 \\
\hline 2 & Produktivitas & Keuntungan & 0,30 \\
\hline 3 & Usia & Biaya & 0,25 \\
\hline 4 & Sakit & Biaya & 0,10 \\
\hline
\end{tabular}

\subsection{Menentukan Matriks Keputusan}

Dalam langkah selanjutnya adalah membuat matriks keputusan variable (x) dari table kecocokan pada pilihan alternatif yang ada dengan berbagai kreteria yang telah ditentukan dengan menggunakan rumus (1), sehingga perhitungan bisa tergambarkan seperti pada paparan tabel 9 yakni normalisasi dari kriteria absen, paparan tabel 10 yakni normalisasi dari kriteria produktivitas, paparan tabel 11 yakni normalisasi dari kriteria usia dan terakhir paparan tabel 12 yakni normalisasi dari kriteria sakit. 
Tabel 9 Hasil Normalisasi Kriteria Absen

\begin{tabular}{|c|l|c|}
\hline No & \multicolumn{1}{|c|}{ Nama } & Absensi \\
\hline 1 & Walim Haryanto & 0,6 \\
\hline 2 & Nian Bahrul & 0,2 \\
\hline 3 & Yusuf & 1 \\
\hline 4 & Eko Suparyadi & 0,8 \\
\hline 5 & Supriyatna & 1 \\
\hline 6 & Lardi & 0,4 \\
\hline 7 & Ragil Suripto & 0,2 \\
\hline 8 & Goretta Ady & 0,6 \\
\hline 9 & Ranto & 1 \\
\hline 10 & Matsani & 0,2 \\
\hline
\end{tabular}

Tabel 10 Hasil Normalisasi Kriteria Produktivitas

\begin{tabular}{|c|l|c|}
\hline No & \multicolumn{1}{|c|}{ Nama } & Produktivitas \\
\hline 1 & Walim Haryanto & 1 \\
\hline 2 & Nian Bahrul & 1 \\
\hline 3 & Yusuf & 0,75 \\
\hline 4 & Eko Suparyadi & 1 \\
\hline 5 & Supriyatna & 1 \\
\hline 6 & Lardi & 1 \\
\hline 7 & Ragil Suripto & 1 \\
\hline 8 & Goretta Ady & 1 \\
\hline 9 & Ranto & 1 \\
\hline 10 & Matsani & 1 \\
\hline
\end{tabular}

Tabel 11 Hasil Normalisasi Kriteria Usia

\begin{tabular}{|c|l|c|}
\hline No & \multicolumn{1}{|c|}{ Nama } & Usia \\
\hline 1 & Walim Haryanto & 1 \\
\hline 2 & Nian Bahrul & 1 \\
\hline 3 & Yusuf & 1 \\
\hline 4 & Eko Suparyadi & 1 \\
\hline 5 & Supriyatna & 1 \\
\hline 6 & Lardi & 1 \\
\hline 7 & Ragil Suripto & 0,67 \\
\hline 8 & Goretta Ady & 0,67 \\
\hline 9 & Ranto & 1 \\
\hline 10 & Matsani & 0,67 \\
\hline
\end{tabular}

Tabel 12 Hasil Normalisasi Kriteria Sakit

\begin{tabular}{|c|l|c|}
\hline No & \multicolumn{1}{|c|}{ Nama } & Sakit \\
\hline 1 & Walim Haryanto & 0,25 \\
\hline 2 & Nian Bahrul & 1 \\
\hline 3 & Yusuf & 0,2 \\
\hline 4 & Eko Suparyadi & 0,2 \\
\hline 5 & Supriyatna & 0,33 \\
\hline 6 & Lardi & 0,33 \\
\hline 7 & Ragil Suripto & 0,5 \\
\hline 8 & Goretta Ady & 0,25 \\
\hline 9 & Ranto & 0,2 \\
\hline 10 & Matsani & 1 \\
\hline
\end{tabular}

\subsection{Menentukan Perangkingan}

Langkah terakhir yaitu, menghitung hasil akhir nilai preferensi $\left(\mathrm{V}_{\mathrm{i}}\right)$ diperoleh dari penjumlahan dari perkalian elemen baris matriks ternormalisasi $(\mathrm{R})$ dengan bobot preferensi (W) seperti pada rumus (2). Dan menghasilkan rangking pada tabel 13 .

Tabel 13 Hasil perengkingan

\begin{tabular}{|c|l|c|}
\hline No & \multicolumn{1}{|c|}{ Alternatif } & $\begin{array}{c}\text { Hasil } \\
\text { Akhir }\end{array}$ \\
\hline 1 & Walim Haryanto & 0,785 \\
\hline 2 & Nian Bahrul & 0,720 \\
\hline 3 & Yusuf & 0,845 \\
\hline 4 & Eko Suparyadi & 0,850 \\
\hline 5 & Supriyatna & 0,933 \\
\hline 6 & Lardi & 0,723 \\
\hline 7 & Ragil Suripto & 0,588 \\
\hline 8 & Goretta Ady S & 0,703 \\
\hline 9 & Ranto & 0,920 \\
\hline 10 & Matsani & 0,638 \\
\hline
\end{tabular}

Berikut ini tampilan menu utama dalam penambahan data karyawan pada PT Nobi Putra Angkasa pada gambar 3 .

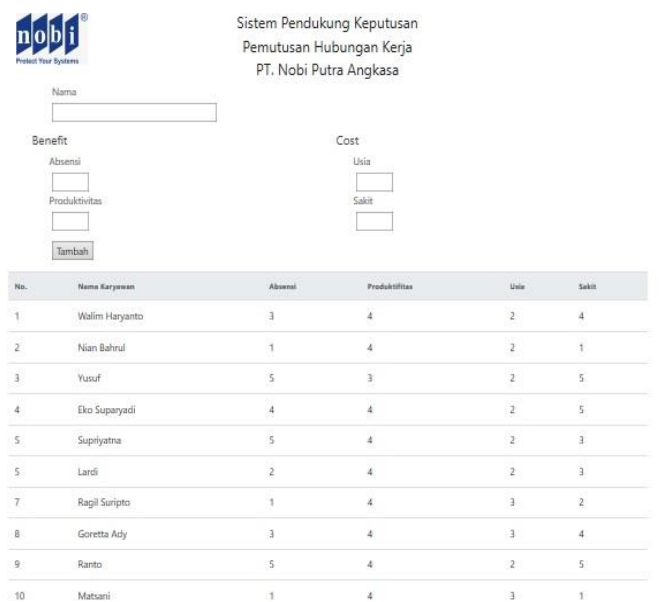

Gambar 3 Menu Tambah Karyawan

Adapun tampilan hasil normalisasi data karyawan PT Nobi Putra Angkasa setelah melakukan matrik kecocokan ada pada gambar 4 


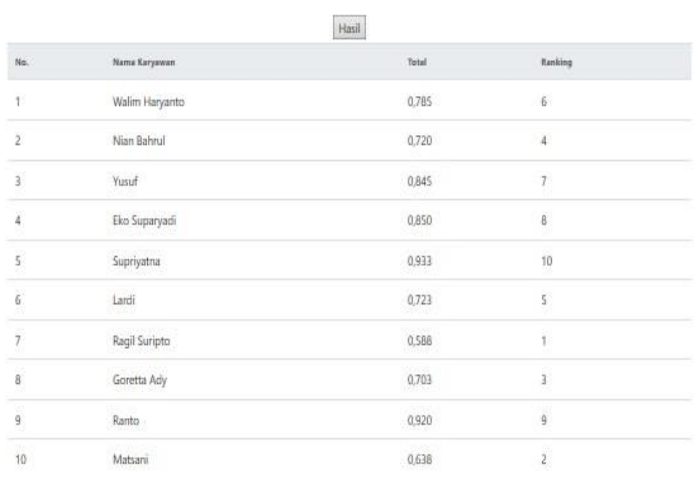

Gambar 4 Menu Hasil Normalisasi

Adapun tampilan hasil normalisasi data karyawan PT Nobi Putra Angkasa setelah melakukan matrik kecocokan ada pada gambar 5 .

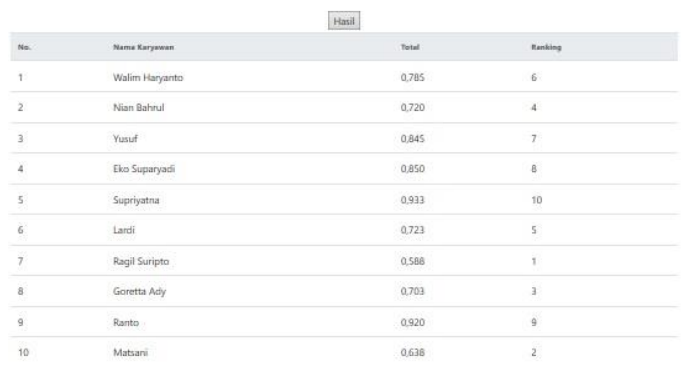

Gambar 5 Menu Hasil Rangking

\section{PENUTUP}

\subsection{Kesimpulan}

Dari hasil penelitian dan pembasan yang sudah dilakukan maka penulis menyimpulkan :

1. Sistem pendukung keputusan dengan menggunakan metode SAW ada beberapa tahap proses pengolahan informasi, pertama menentukan kriteria, kedua mentukan nilai kriteria, ketiga menentukan bobot setiap kriteria dan yang keempat menentukan rangking dari alternatif yang ada. Dari studi kasus pemutusan hubungan kerja terhadap karyawan menggunakan metode SAW dapat menghasilkan alternatif pilihan karyawan yang memiliki penilaian rendah yaitu alternatif A7 Ragil Suripto yang mempunyai nilai $\mathrm{V}=0,588$.

2. Dengan menggunakan metode Simple Additve Weighting (SAW) untuk pemutusan hubungan kerja terhadap karyawan pada PT. Nobi Putra Angkasa diperhitungkan berdasarkan kriteria - kriteria yang ada diantaranya, Absensi, Produktivitas, Usia, dan Sakit.

3. Pembobotan yang digunakan dalam pemutusan hubungan kerja terhadap karyawan pada PT. Nobi Putra Angkasa yaitu terdiri dari 0,35 untuk Absensi, 0,30 untuk Produktivitas, 0,25 untuk Usia, dan 0,10 untuk Sakit, bobot ini didapatkan berdasarkan dari jurnal ilmiah dan hasilwawancaralangsung dengan Ibu Nina Putri Andalawati, S.M selaku bagian HRD pada PT. Nobi Putra Angkasa.

\subsection{Saran}

Untuk menentukan penilaian karyawan dan menyempurnakan sistem pendukung keputusan yang telah dibuat, peneliti memberikan saran sebagai berikut :

1. Dalam penelitian ini, untuk pemutusan hubungan kerja terhadap karyawan pada PT. Nobi Putra Angkasa hanya terdapat 4 kriteria - kriteria yaitu Absensi, Produktivitas, Usia dan Sakit. Untuk pengembangan sistem pengambilan keputusan ini dapat ditambahkan beberapa variabel nilai lain yang mungkin dapat memperkuat hasilkeputusan.

2. Sistem pendukung keputusan pemutusan hubungan kerja terhadap karyawan dengan metode Simple Additive Weighting (SAW) untuk membantu perusahaan dalam memberikan status PHK bagi karyawan yang memiliki penilaian rendah.

3. Bagi perusahaan yang ingin menentukan penilaian karyawan yang penilaiannya rendahalangkah baiknya memperhitungkan setiap kriteria - kriteria yang diperlukan sesuai dengan kriteria yang sesuai dengan kebijakan perusahaan.

\section{DAFTAR PUSTAKA}

[1] M. Mesran, R. Rusiana, and M. Sianturi, "Decision Support System for Termination of Employment using Elimination and Choice Translation Reality Method," $J$. Teknol. dan Sist. Komput., vol. 6, no. 4, p. 135, 2018.

[2] D. Andrianto et al., "Sistem Pendukung Keputusan Pemutusan Hubungan Kerja Terhadap Karyawan Menggunakan Metode Analytical Hierarchy Process Di Pt Sansan Saudaratex Jaya," pp. 67-72, 2017.

[3] S. R. S. Siregar and D. P. Prabowati, "Perancangan Sistem Pendukung Keputusan Pemberhentian Karyawan Harian Lepas ( Studi Kasus di CV Mitra Abadi Jaya Tangerang )," Sisfotek Glob., vol. 5, no. 2, pp. 109-116, 2015.

[4] I. Fahmi, Manajemen Pengambilan Keputusan, Cetakan Ke. Bandung: CV.Alfabeta, 2016. 
[5] S. A. U. B. Surakarta, "KEPUTUSAN PEMILIHAN SUSU FORMULA BALITA Robby Rachmatullah , Heribertus Ary Setyadi," vol. 21, no. 2, pp. 1-8, 2015.

[6] D. Nofriansyah, Konsep Data Mining Vs Sistem Pendukung Keputusan. Yogyakarta: Deepublish, 2015.

[7] A. Salim and B. O. Lubis, "Sistem Pendukung Keputusan Pemilihan Jenis Tablet Gaming dengan Menggunakan Analytical Hierarchy Process," Pros. Semin. Nas. Energi Telekomun. dan Otomasi, no. ISBN: 978-602-74127-4-3, pp. 1-9, 2017.

[8] U.-U. R. I. N. 1. T. 2003 T. Ketenagakerjaan, Undang-Undang Republik Indonesia No.13 Tahun 2003. Jakarta: Sekretaris Negara Republik Indonesia, 2003.

[9] U.-U. N. 1. T. 1969 T. K. P. T. Kerja, Undang-Undang No.14 Tahun 1969 Tentang Ketentuan-Ketentuan Pokok Mengenai Tenaga Kerja. Jakarta: Sekretaris Negara Republik Indonesia, 1969.

[10] M. Dr.Kasmir, S.E, Manajemen Sumber Daya Manusia. Depok: PT.RajaGrafindo Persada, 2018.
[11] D. Nofriansyah, Konsep Data Mining Vs Sistem Pendukung Keputusan. Yogyakarta: Deepublish, 2015.

[12] J. Speed and S. P. Engineering, "518-6811-Sm," vol. 8, no. 2, pp. 23-32, 2016.

[13] M. Al Amin, "Klasifikasi Kelompok Umur Manusia Berdasarkan Analisis Dimensifraktal Box Counting Dari Citra Wajah Dengan Deteksi Tepi Canny," MATHunesa, vol. 2, no. 6, 2017.

[14] H. T. Sihotang and M. Siboro, "Aplikasi Sistem Pendukung Keputusan Penentuan Siswa Bermasalah Menggunakan Metode Saw Pada Sekolah SMP Swasta Mulia Pratama Medan," J. Informatics Pelita Nusant., vol. 1, no. 1, pp. 1-6, 2016.

[15] Sunarti, J. Sundari, S. Anggraeni, F. B. Siahaan, and Jimmi, "Comparison topsis and saw method in the selection of tourism destination in Indonesia," Proc. 3rd Int. Conf. Informatics Comput. ICIC 2018, pp. 1-6, 2018. 